\title{
Introduction: Innovation in Hindu Traditions
}

\author{
Jonathan Edelmann
}

This themed issue of the International Journal of Hindu Studies is about the historical, philosophical, and theological factors involved in speaking about change, innovation, and newness in Hindu traditions, especially Mādhva Vaiṣnava, Gauḍiya Vaiṣnava, contemporary Advaita, and popular forms of contemporary Hinduism. The underlying question addressed in this issue is: In what manner did Hindu thinkers and Hindu leaders create newness and intellectual innovation? This question has lately received attention from scholars, and it is to this body of scholarship that this issue hopes to contribute.

Hindu śāstras frequently say their views are timeless, immortal, or entirely lacking newness, and likewise Hindu theologians and philosophers frequently frame their own teachings as nothing but a restatement of an ancient root text's original intent and meaning or as clarifying its meaning without any substantive change to the philosophies and theologies of their own previous teachers. As demonstrated in the papers in this issue of the IJHS, from an Indological and historical perspective, these claims simply cannot be true. The acceptance of such theses would also, I believe, undermine the brilliance and fecundity of Indian intellectuals, reducing them to mere parrots rather than independently thoughtful, creative, and constructive authors. There is a real sense in which the Hindu thinkers represented here are in fact creative and constructive thinkers, even when their new philosophies and theologies are justified through exegesis of root texts, through exegesis of authoritative teachers in their tradition, or as reconstructions of a premodern or forgotten time.

International Journal of Hindu Studies 18, 2: 113-118

(C) 2014 Springer

DOI 10.1007/s11407-014-9155-9 
This is the first issue of the IJHS to be fully dedicated to Hindu theology, and I wish to say a bit about what the term "Hindu theology" might mean in the context of an academic journal devoted to the study of Hinduism. I will discuss how and why the theme of "innovation" is so vital to any constructive discussion of Hinduism in a contemporary intellectual context. Theology, broadly speaking, is a logical and rational investigation into the nature of God (for example, brahman, bhagavat, iśvara, and so on), things related to religious practice (dharma, yajña, yoga, and so on), or the nature of the divine's relationship with the world and the self (ätman, jivva, purușa, and so on). In the course of investigating such issues, other topics must arise such as epistemology, philosophy of language, the nature of the mind, world, and body, and so forth. Often these other topics are in the service of underpinning or clarifying the sorts of larger religious issues mentioned above. Theology is also a discipline that, like others, takes "tradition" seriously in its reflection, and in a Hindu context that would mean a critical and exegetical reflection on specific śăstras and their learned commentators. As noted in this issue, while many Hindu thinkers depict themselves as providing exegesis, they are often of independent minds in doing so and use the exegetical process as a way of articulating their own views. Theologians often see themselves as speaking to or informing the religious communities in which they participate, and in Hindu contexts the ācāryas, learned gurus, respected commentators, and so on, often do inform, guide, and shape the sampradāyas in which they participate. Contemporary Mādhva, Gauḍiya Vaiṣnava, and Advaita religious communities continue to read and quote their learned teachers of the past as authorities for the present.

If we take Hindu theology as a genitive tat-purusa, it means a rational investigation of God dharma, and so on, by people who identify with or are identified as members of and speakers for particular Hindu communities. The term "Hindu" does not implicate one in thinking of Hinduism is a monolithic category any more than the terms "Christian theology" or "Western philosophy" entail a singular Christian or Western view. As will be demonstrated in this issue, the sorts of problems and their manners of solution are varied among Mādhva, Gauḍiya Vaiṣnava, Advaita, and contemporary Hindu approaches.

The ability of a religious tradition to respond to the present, yet another feature of a theologian, requires an understanding of how thinkers in the 
past responded to the present that was their own. We have, therefore, framed the papers around the issue of "innovation" in a historical mode. The assumption of each paper is that a clear and objective understanding of history - and for our purposes, the historical interpretation of scriptural texts by the theologians of the tradition-is necessary for an informed discussion about how Hindu traditions can respond critically and constructively to contemporary theological, philosophical, political issues.

We have arranged the papers according to the historical periods they address, with the oldest first, something that will allow us to see the manner in which innovation itself is addressed differently over time given the new social, political, and intellectual situations Hindus encountered.

We start with Michael Williams' paper, which provides us with an indepth examination of a critical period in the history of Mādhva Vedānta, when Vyāsatīrtha (1460-1539) not only encountered, but sought to assimilate aspects of Navya-Nyāya. Williams notes that Vyāsatīrtha acknowledges that his Nyāyamrta says things that had "not been said" (anukta) in the works of his predecessors Madhva (1238-1317) and Jayatìrtha (fourteenth century). Vyāsatīrtha's disciple and first commentator, Vijayīndratîrtha, is unalarmed by this statement, saying that his guru only meant that he taught things that the previous ācarryas had known, but for one reason or another had chosen not to say. The novel contributions of Vyāsatīrtha are unproblematic, it appeared to Vijayīndratīrtha, because Vyāsatīrtha was only saying what the previous ācāryas thought but did not say. Approximately one century later Ānandabhatțāaka (flourished early seventeenth century) was concerned with Vyāsatīrtha's statement, and in seeking to make sense of it, he articulated an attitude toward his predecessors that is perhaps more familiar to the student of Indian thought, one that shows the anxiety about innovation. Wouldn't saying something that was "unsaid" by the previous ācāryas imply that they left something out? Wouldn't they then be lazy, lacking in deliberation, or deficient? Positing innovation implies that one's teachers were incompetent or in need of correction. That sort of thinking about the previous ācāryas was unacceptable, so Ānandabhațāaraka takes it upon himself to interpret Vyāsatīrtha as merely saying his Nyāyāmrta discusses what is "apprehended (pratīyamānatvam) as though it were unsaid." Ānandabhatțāraka seems to imply that Vyāsatīrtha only wants to illuminate what we, the reader, might fail to notice in the otherwise flawless works of the previous 
Mādhva teachers. Williams argues, however, that Vyāsatīrtha sought to establish himself "as a thinker working with a definite independence of thought, albeit within a preexisting framework," and we are given specific instances of Vyāsatīrtha's assimilation of Navya-Nyāya logic, not just as fancy new ways of saying the same thing, but as substantively new Mādhva theology and philosophy.

Our second paper is from Kiyokazu Okita, who offers a detailed examination of the concept of adhikāra ("qualification" or "eligibility") in the work of an early and founding member of the Gaudiyya or Caitanya Vaiṣnava tradition, Rūpa Gosvāmī (sixteenth century), as it applies to the sorts of prerequisites needed to study the esoteric and religiously erotic texts of the tradition, especially the Vidagdhamädhava and the Ujjvalanìlamani. As demonstrated by Okita, the later tradition had sought to close these texts off from those who were considered nonadepts, saying that prior to their study one needed to be qualified for certain religious practices (sädhana) meant only for the well-seasoned and expert devotees and one needed a deep learning of the corpus of introductory and middlelevel texts of the tradition. On a personal level, Okita notes how he, being perceived as unqualified, has been discouraged from studying the texts by contemporary Gauḍīya scholars. Rūpa Gosvāmī's articulations of adhikāra are thus still used today to guide the tradition. Undoubtedly other students of Indian religion have experienced much the same in other religious contexts. Okita problematizes the very notion of adhikāra as defined by Rūpa Gosvāmī and his commentators by engaging the presuppositions of the tradition itself, not by disregarding it as meaningless or antiquated, but by attempting to make sense of it in a new context. In doing so he seeks to develop a conception of Hindu theology that opens the study of esoteric texts to those who might otherwise lack the rather demanding moral and practical attributes of an adept, yet one that "remains respectful and sensitive to the insider perspective." This, he argues, is going to require a "phenomenological perspective," one that is aware of the philological, ontological, narrative, and commentarial aspects of the tradition one studies. This presents us with a constructive theory on the theological method. Okita's paper thus contributes to the growing discussion on Hindu theology, suggesting that there are ways to change existing norms in the Gaudịya Vaiṣnava sampradāya that are in fact new and different but are nevertheless not inconsistent with its history and tradition. 
Moving ahead in time to the early part of the last century, Timothy S. Dobe enunciates a rich theoretical architecture through which we can understand Rāma Tīrtha (1873-1906), a Punjabi "Neo-Vedāntin" shaped by Advaita, bhakti, and Șūfī lines of thought. With Rāma Tīrtha we are in a period of time when Hindu literature is for the most part composed and read in vernacular languages, as it is today, and a time when new genres of Hindu literature are emerging due to more intimate contact with Western culture and due to the Indian appropriation of printing press technology. In the case of Rāma Tïrtha's writing there is the unification of the reporting of subjectively experienced "mystical" states, autobiography, hagiography, and religious instruction. Yet this "self-writing," as Dobe calls it, is constructed and idealized, something Dobe refers to as "autohagiographical." Nevertheless in ways that were not possible before this period we get a chance to see something of the life and times "from the inside" of a renouncer making his way around India, albeit the inside as Rāma Tìrtha wants us, his reader, to see it. Dobe notes that while some would dismiss this sort of writing as a mere product of Western influence since it does not conform to the previous tradition of Brāhmaṇical discourse, we might in fact see such innovative writing as affirming a fundamental Vedāntic concept, the self-revelation of "the One" in the written word.

Bringing us into the world of contemporary Hinduism, Amanda Lucia discusses the diverse range of recent Hindu gurus, particularly those who are popular and with mass appeal, and who, she argues, are some of "the most vibrant innovators in the field of Hindu religiosity." As a global phenomenon, the rate of change, of adaptation, and of reconfiguration in this popular Hindu context is perhaps unprecedented, and Lucia explores some of the common themes, techniques, and methods ("upayya") used by Hindu gurus to create and sustain a discipleship and ministry, focusing on those gurus that have "garnered worldwide attention" but not the existing local lineages that thrive in India and elsewhere. While the gurus reviewed here might not be considered theologians in the sense of giving a reasoned, systematic, and scholastic interpretation of the learned texts and previous teachers in their religious tradition in the way that Vyāsatīrtha, Rūpa Gosvāmī, and Rāma Tìrtha attempted, this contributes to our understanding of the larger social context in which any contemporary Hindu theology would need to speak. Lucia insightfully notes that while the larger Hindu 
tradition is engaged by Hindu gurus (to the extent it is known and understood by the gurus), and while they are and they must be innovative to generate popularity in new contexts that are often radically different than the original contexts, there is a danger that Hinduism will lose a recognizable contact with the past or that the gurus will present mere "nostalgiabased" interpretations of the past in an effort to respond to the perceived problems of the modern world. Knowing how and in what manner contemporary gurus innovate requires two knowledge bases: a detailed knowledge of the historical traditions out of which they emerge and which they claim to represent, and a detailed knowledge of the content of their teaching. Lucia contributes to our understanding of both in this issue of the IJHS.

Lucia has thus taken us in a full circle, from the learned logical and epistemological innovations of a Mādhva scholar that address the needs and interests of similarly learned scholars who were grappling with the new philosophical movements of their day, to the refashioning of the Gaudīya Vaiṣnava conception of the eligibility or the entitlement to study the tradition's most esoteric religious erotica to meet the aspirations of the contemporary Indologist while not ignoring the concerns and needs of practitioners who have lovingly preserved these texts for hundreds of years, to a new genre of mystical self-writing for bhakti infused and Șūfî inspired forms of Advaita Vedānta that served the needs of an emerging literate Hindu middle class. We see here a rich set of patterns and techniques through which one of the world's oldest religious traditions has evolved and remade itself over time in the hands of its caretakers, those who have made the decisions as to what should be preserved and how the preserved should be spoken about, augmented, or reinterpreted.

JONATHAN EDELMANN is Assistant Professor of Religion and Shackouls Honors College Faculty Fellow at Mississippi State University, and Editor for the "Hindu Theology" Section of the International Journal of Hindu Studies.

je374@msstate.edu 